\title{
Study of mast cell and eosinophil count in surgically resected appendix
}

\author{
Priya $^{1}$, Giriyan S.S. ${ }^{2}$ \\ ${ }^{1}$ Dr. Priya, Post Graduate, ${ }^{2}$ Dr. Sujata S. Giriyan, Professor and Head, both authors are affiliated with Department of \\ Pathology, Karnataka Institute of Medical Sciences, Hubballi, Karnataka, India.
}

Corresponding Author: Dr. Priya, Post Graduate, Department of Pathology, Karnataka Institute of Medical Sciences, Hubballi, Karnataka, India. E-mail: mayurirao0116@gmail.com

\begin{abstract}
Introduction: Appendix is a normal true diverticulum of the caecum that is prone to acute and chronic inflammation. Mast cells are present in chronic inflammatory reactions and they secrete cytokines that promote inflammation. Eosinophils are abundant in immune reactions mediated by IgE and in parasitic infection. Objective: To evaluate mast cell and eosinophil count variation in appendicitis and to suggest their possible role in pathogenesis of appendicitis. Materials and Methods: It is a two-year prospective study done on 470 resected specimens of appendices received for histopathology. Results: Mast cells and eosinophils were present in all the appendicular lesions studied. Mean mast cell count was highest in chronic appendicitis and lowest in acute appendicitis. Mucosa of chronic appendicitis showed highest count, lowest was seen in the muscularis propria of acute appendicitis compared to normal / unremarkable appendix taken as controls. Correlation between mast cell density, fibrosis and neural ganglia hypertrophy was seen in chronic appendicitis. Mean eosinophil count was highest in acute suppurative appendicitis and lowest in chronic appendicitis, with highest count in the mucosa of acute suppurative appendicitis and lowest in the muscularis propria of chronic appendicitis. Conclusion: The presence of mast cells and eosinophils in cases of appendicitis supports the allergic theory of appendicitis in which the Type I hypersensitivity reaction leads to recruitment of eosinophils and discharge of primary and secondary mediators of inflammation by degranulation of mast cells which play a role in pathogenesis of appendicitis.
\end{abstract}

Keywords: Appendicitis, Mast cells, Eosinophils, Fibrosis, Hypertrophic neural ganglia, Type I hypersensitivity.

\section{Introduction}

Appendix is a vestigial organ that is prone to acute and chronic inflammation [1]. The lifetime risk for appendicitis is $7 \%$ and is commonly seen in adolescents and young adults. Acute appendicitis is one of the most common surgical causes of acute abdomen [2].

Appendicitis is caused due to obstruction of the lumen. Obstruction may be due to lymphoid hyperplasia, fecolith or fecal stasis, foreign body, tumors [3]. Although the clinical and operative protocols are well known, the pathogenesis of the appendicitis is poorly understood. Despite of advances in technology and imaging modalities, there is dilemma in the clinical diagnosis of acute appendicitis. Histopathological examination still remains the gold standard method for the confirmation of the appendicitis.

Mast cells and eosinophils are seen in all the appendicular lesions. Mast cells are derived from the

Manuscript received: $30^{\text {th }}$ August 2019

Reviewed: $10^{\text {th }}$ September 2019

Author Corrected: $15^{\text {th }}$ September 2019

Accepted for Publication: $19^{\text {th }}$ September 2019 multipotent stem cells in the bone marrow and they contain many histamine and heparin- rich granules. Mast cells possess protective functions such as wound healing and defense against pathogens [4]. Eosinophils are abundant in immune reactions mediated by $\operatorname{IgE}$ and in parasitic infections [1].

This study was taken up with the objective to find the mast cell and eosinophil count variation in appendicitis, and to suggest the possible role of mast cells and eosinophils in the pathogenesis of appendicitis.

\section{Materials and Methods}

Duration of study: The present study was done on all the surgically resected specimens of appendix received for the routine histopathological evaluation in the Department of Pathology, Karnataka Institute of Medical Sciences, Hubballi between July 2015 to June 2017.

Type of study: Prospective study.

Sampling method: This study was conducted on 470 appendix specimens taken as per the inclusion criteria. Surgically resected specimens of appendix received for 
Original Research Article

the routine histopathological evaluation was taken for study.

\section{Inclusion criteria:}

1] All specimens of appendix resected for clinically suspected appendicitis were included.

2] Appendices removed as a part of ileo-caecal resections or laparotomies done for some other diseases were included.

Exclusion criteria: Acute gangrenous appendicitis was excluded due to necrosis of muscle fibres.

Data collection procedure: All appendix specimens received in 10\% formalin in the Department of Pathology were studied. Minimum of 24 hours was allowed for fixation.

The details of the patient like age, sex, presenting symptoms, clinical diagnosis were noted as per the proforma. After fixation each specimen was examined and gross features were noted down.

Gross examination was done noting the length of appendix, presence of meso appendix and other external features like congestion, exudates, perforation.

Sections for the study were taken from the tip and one intermediate site along the length of the appendix in normal looking appendix and in suspected cases of appendicitis. In other cases, sections were taken depending upon the area of lesion involved.

After routine processing and embedding of tissue sections in paraffin blocks, two sections of 5 microns thickness were cut from each paraffin block. One section was stained with Hematoxylin and Eosin (Annexure 1) to study the various findings of appendicitis and to count the eosinophils and the other section was stained with $1 \%$ Toluidine blue (Annexure 1) for the identification and counting of mast cells.

Based on the clinical and histopathological features three groups were made and the mast cell and eosinophil count was done in different layers of the appendix according to the groups made.

Group A: Cases of acute appendicitis including acute suppurative appendicitis,

Group B: Cases of chronic appendicitis,

Group C: Normal / Unremarkable appendix.

The counting of mast cells and eosinophils in the mucosa, submucosa and muscularis propria was done under high power of the microscope (100X). Counting was commenced from the field in which first cell (mast cell, eosinophil) was sighted.

The average count obtained in 10 non overlapping high power fields was considered. The degree of eosinophil infiltration, mast cell density and their count in various histopathological groups was studied.

Data analysis: It was done using appropriate statistical tests.

\section{Ethical consideration and permission: Taken.}

\section{Results}

Appendicitis was commonly seen in 21-30 years (35.1\%). Least number of cases were seen in elderly age group above 70 years. Mean age of presentation was 26.6 years. Of the total 470 cases, 288 cases (61\%) were males and 182 cases (39\%) were females. Male to female ratio was found to be 1.56: 1 .

The most common cause for the resection of appendix was clinically suspected appendicitis which accounted for $95.1 \%$ of cases.

Based on histopathological findings the cases were classified into three groups. Group A constituted 96 cases (20.4\%) of acute appendicitis and 174 cases (37\%) of acute suppurative appendicitis, Group B constituted 177 cases (37.7\%) of chronic appendicitis, Group C constituted 23 cases (4.9\%) of normal / unremarkable appendix. Acute appendicitis including acute suppurative appendicitis was more common than chronic appendicitis.

Mean mast cell count was found to be highest in chronic appendicitis (17.0土5.4), followed next in frequency by acute

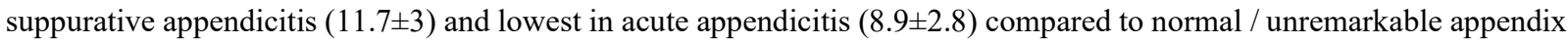
taken as controls.

Highest mean mast cell count was seen in mucosa of chronic appendicitis (Figure 1), lowest was seen in muscularis propria of acute appendicitis (Figure 2) compared to normal / unremarkable appendix taken as controls. 
Original Research Article

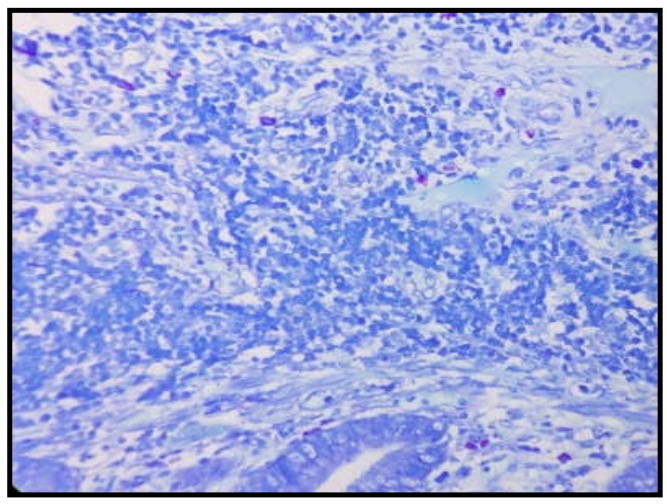

Figure-1: Microscopy- Chronic appendicitis showing mast cells around the mucosal glands and in lamina propria. (40X, $1 \%$ Toluidine blue stain).

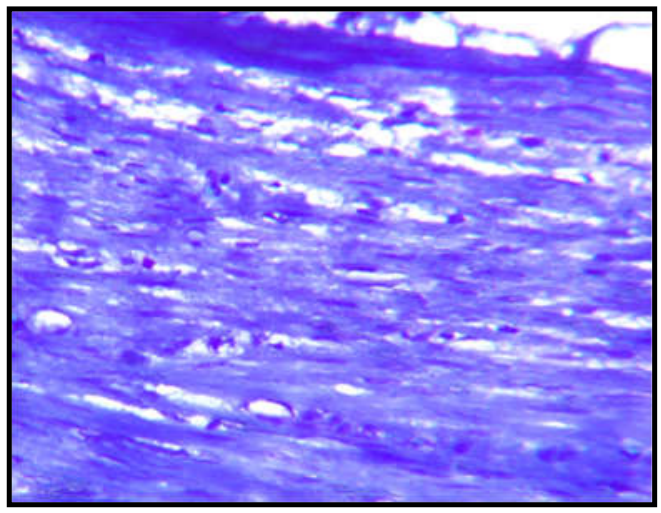

Figure-2: Microscopy- Acute appendicitis showing mast cells in the muscularis propria. (40X, $1 \%$ Toluidine blue).

In chronic appendicitis, acute suppurative appendicitis and acute appendicitis mean mast cell count was highest in mucosa followed by submucosa and muscularis propria. Mean mast cell count in all the appendicular lesions was highest in mucosa $>$ submucosa $>$ muscularis propria.

A correlation between mast cells density, fibrosis and neural ganglia hypertrophy was seen in cases chronic appendicitis (Figure 3).

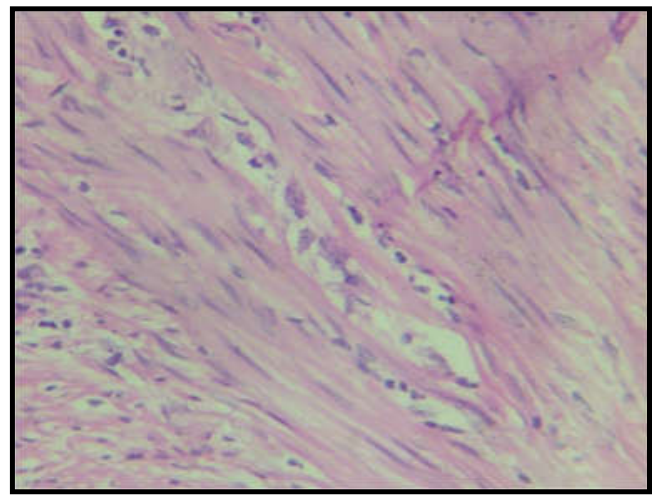

Figure-3: Microscopy- Chronic appendicitis showing hypertrophy of neural ganglia in muscularis propria. (40X, $\mathrm{H}$ and $\mathrm{E}$ stain).

Mean eosinophil count was highest in acute suppurative appendicitis $(30 \pm 11.5)$ followed next in frequency by acute

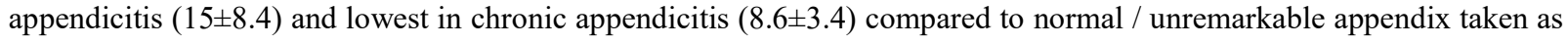
control group. 
Highest eosinophil count was seen in the mucosa of acute suppurative appendicitis (Figure 4) and lowest eosinophil count was seen in the muscularis propria of chronic appendicitis (Figure 5) compared to normal / unremarkable appendix taken as control.

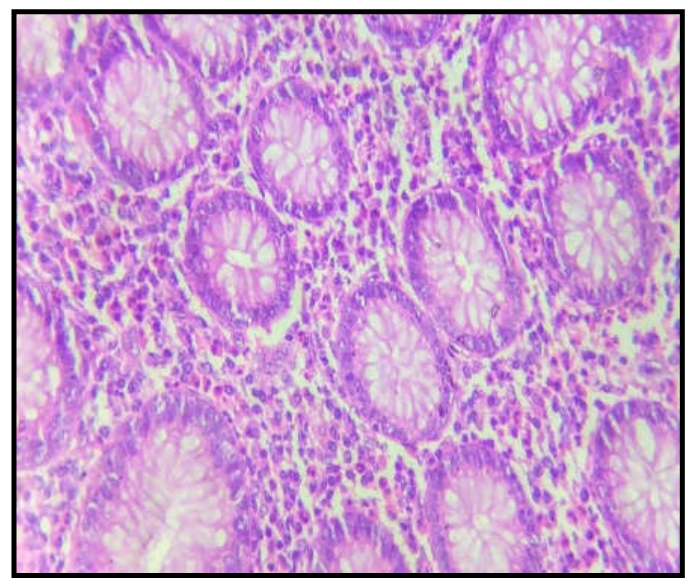

Figure-4: Microscopy- Acute suppurative appendicitis showing neutrophils and eosinophils in the mucosa. (40X, $\mathrm{H}$ and $\mathrm{E}$ stain).

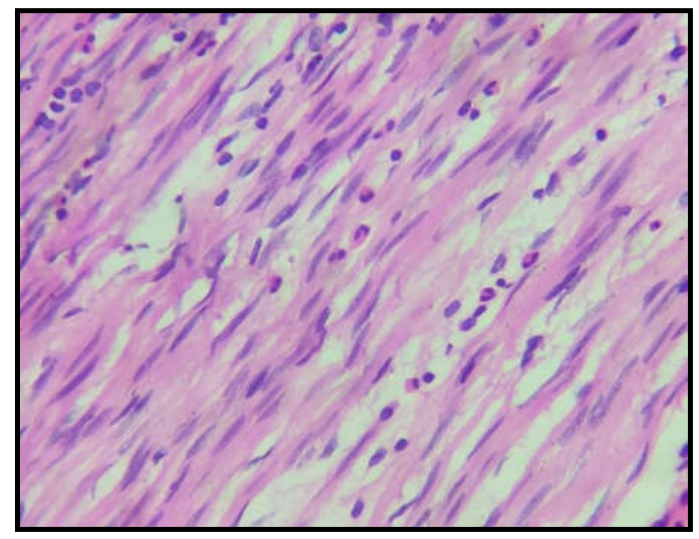

Figure-5: Microscopy- Chronic appendicitis showing eosinophils in the muscularis propria. (40X, $\mathrm{H}$ and $\mathrm{E}$ stain).

In acute suppurative appendicitis and acute appendicitis, mean eosinophil count was highest in mucosa followed by muscularis propria and then submucosa, and in chronic appendicitis, mean eosinophil count was highest in mucosa followed by submucosa and then muscularis propria compared to normal / unremarkable appendix taken as control.

\section{Discussion}

Appendicectomy is the most frequently performed intra-abdominal surgery and appendicitis is the most common cause for appendicectomy. Diagnosis of appendicitis is based on clinical, imaging and histopathology. Histopathology being the gold standard for diagnosis [5]. Mast cells and eosinophils are seen in all the layers of appendix. Mast cells have a central role in Type I hypersensitivity leading to recruitment of eosinophils and discharge of primary and secondary mediators of inflammation $[5,6]$.

Eosinophilic infiltration of muscularis propria has been seen in acute appendicitis and it is postulated that acute appendicitis is triggered by Type I hypersensitivity [6]. Hence mast cells and eosinophils have important role to play in the pathogenesis of appendicitis as concluded by many studies $[4,5,6,7,8,9,10,11,12]$.

In the present study highest mast cell count was seen in mucosa of chronic appendicitis. Lowest mast cell count was seen in muscularis propria of acute appendicitis. 
Original Research Article

Table-1: Comparison of mean mast cell count in different layers of appendix in various cases in the present study with other studies.

\begin{tabular}{|l|l|c|c|c|c|}
\hline \multicolumn{2}{|c|}{} & $\begin{array}{c}\text { Sonti S } \\
{[8]}\end{array}$ & $\begin{array}{c}\text { Verma A et al } \\
{[13]}\end{array}$ & $\begin{array}{c}\text { Kolur A et al } \\
{[7]}\end{array}$ & $\begin{array}{c}\text { Present } \\
\text { study }\end{array}$ \\
\hline \multirow{4}{*}{$\begin{array}{l}\text { Acute } \\
\text { appendicitis }\end{array}$} & $\begin{array}{l}\text { Mucosa } \\
\text { (Mean } \pm \text { SD) }\end{array}$ & 30 & $10 \pm 3$ & $8.8 \pm 4.2$ & $\mathbf{3 . 7} \pm \mathbf{1 . 1}$ \\
\cline { 2 - 6 } & Submucosa (Mean \pm SD) & 36 & $12.5 \pm 3.72$ & $8.48 \pm 4.48$ & $\mathbf{2 . 3} \pm \mathbf{1 . 1}$ \\
\cline { 2 - 6 } & $\begin{array}{l}\text { Muscularis propria } \\
\text { (Mean } \pm \text { SD) }\end{array}$ & 30 & $14.12 \pm 3.8$ & $8.16 \pm 3.8$ & $\mathbf{2 . 2} \pm \mathbf{0 . 8}$ \\
\hline \multirow{2}{*}{$\begin{array}{l}\text { Chronic } \\
\text { appendicitis }\end{array}$} & Mucosa (Mean \pm SD) & 49 & $18.21 \pm 3.80$ & $11.3 \pm 6.1$ & $\mathbf{7 . 0} \pm \mathbf{2 . 0}$ \\
\cline { 2 - 6 } & Submucosa (Mean \pm SD) & 46 & $16.78 \pm 3.40$ & $10.2 \pm 5.8$ & $\mathbf{5 . 6} \pm \mathbf{1 . 8}$ \\
\cline { 2 - 6 } & Muscularis propria (Mean \pm SD) & 49 & $17.17 \pm 3.8$ & $9.99 \pm 5.6$ & $\mathbf{4 . 6} \pm \mathbf{1 . 7}$ \\
\hline \multirow{2}{*}{$\begin{array}{l}\text { Normal } \\
\text { unremarkable } \\
\text { appendix }\end{array}$} & Mucosa (Mean \pm SD) & 47 & $5.2 \pm 1.7$ & $7.2 \pm 3.7$ & $\mathbf{0 . 5} \pm \mathbf{0 . 2}$ \\
\cline { 2 - 6 } & Submucosa (Mean \pm SD) & 40 & $5 \pm 1.4$ & $8.15 \pm 4.7$ & $\mathbf{0 . 3} \pm \mathbf{0 . 1}$ \\
\cline { 2 - 6 } & Muscularis propria (Mean \pm SD) & 47 & $5 \pm 1.46$ & $9.38 \pm 4.9$ & $\mathbf{0 . 2} \pm \mathbf{0 . 1}$ \\
\hline
\end{tabular}

Concordant results with the present study were seen in studies done by Nagaraj et al [4], Sonti S [8], Mysorekar VV et al [12], Verma A et al [13], Sharma J et al [14], Kumaran C et al [15] who also found highest mast cell counts in chronic appendicitis, followed next in frequency by acute appendicitis and lowest in normal appendices. Comparison of mean mast cell count in different layers of appendix in various cases in the present study with other studies is shown in Table 1 . In the present study the mean mast cell count was found to be highest in mucosa followed by submucosa and then muscularis propria, but study by Verma A et al [13] found that mast cells were more easily identified in submucosa.

Table-2: Comparison of mean eosinophil count in different layers of appendix in various cases in the present study with other study.

\begin{tabular}{|c|c|c|c|}
\hline & & Kolur A et al [7] & Present study \\
\hline \multirow{3}{*}{ Acute appendicitis } & $\begin{array}{c}\text { Mucosa } \\
(\text { Mean } \pm \text { SD })\end{array}$ & $23.7 \pm 10.7$ & $6.0 \pm 2.8$ \\
\hline & Submucosa $($ Mean \pm SD) & $24.5 \pm 11.3$ & $4.1 \pm 2.7$ \\
\hline & $\begin{array}{l}\text { Muscularis propria } \\
\quad(\text { Mean } \pm \text { SD })\end{array}$ & $22.4 \pm 9.7$ & $5.0 \pm 2.9$ \\
\hline \multirow{3}{*}{$\begin{array}{l}\text { Acute suppurative } \\
\text { appendicitis }\end{array}$} & $\begin{array}{c}\text { Mucosa } \\
(\text { Mean } \pm \text { SD) }\end{array}$ & $25.94 \pm 11.8$ & $11.0 \pm 3.8$ \\
\hline & $\begin{array}{c}\text { Submucosa } \\
(\text { Mean } \pm \text { SD) }\end{array}$ & $26.1 \pm 10.3$ & $8.8 \pm 4.0$ \\
\hline & $\begin{array}{l}\text { Muscularis propria } \\
\quad(\text { Mean } \pm \mathrm{SD})\end{array}$ & $18.5 \pm 6.6$ & $10.0 \pm 3.9$ \\
\hline \multirow{3}{*}{ Chronic appendicitis } & $\begin{array}{c}\text { Mucosa } \\
(\text { Mean } \pm \text { SD })\end{array}$ & $34.2 \pm 18.6$ & $3.4 \pm 1.0$ \\
\hline & Submucosa $($ Mean \pm SD $)$ & $30 \pm 18.2$ & $2.8 \pm 1.0$ \\
\hline & $\begin{array}{l}\text { Muscularis propria } \\
(\text { Mean } \pm \mathrm{SD})\end{array}$ & $28.2 \pm 16.8$ & $2.2 \pm 1.0$ \\
\hline \multirow{3}{*}{$\begin{array}{l}\text { Normal/ } \\
\text { Unremarkable } \\
\text { appendix }\end{array}$} & $\begin{array}{c}\text { Mucosa } \\
(\text { Mean } \pm \mathrm{SD})\end{array}$ & $28.4 \pm 12.5$ & $0.4 \pm 0.1$ \\
\hline & Submucosa $($ Mean \pm SD $)$ & $26.2 \pm 11.5$ & $0.2 \pm 0.1$ \\
\hline & $\begin{array}{l}\text { Muscularis propria } \\
(\text { Mean } \pm \mathrm{SD})\end{array}$ & $21.2 \pm 10.3$ & $0.2 \pm 0.1$ \\
\hline
\end{tabular}

In comparison of the findings in the present study and study by Kolur A et al [7], mean mast cell count was highest in chronic appendicitis, followed next in frequency by acute appendicitis and acute suppurative appendicitis compared to normal / unremarkable appendix and the mean mast cell count in chronic appendicitis and acute appendicitis was highest in the mucosa, followed by submucosa and muscularis propria in Kolur A et al [7] study, these results were in concordance with the present study. 
Original Research Article

Study by Kolur A et al [7] showed few contrary results with the present study, where they found the mean mast cell count in acute suppurative to be highest in muscularis propria followed by mucosa then submucosa, however in the present study the mean mast cell count was found to be highest in the mucosa, followed by submucosa then muscularis propria. Increase in mast cells in acute appendicitis together with the broad spectrum of activities of mast cell derived mediators was seen in studies done by Sonti S [8], Sharma J et al [14], Kumaran C et al [15] and Bhramarambha K et al [11]. They suggested that mast cell could play a role in the pathogenesis of acute appendicitis. Their finding was different from the present study.

Presence of mast cell in cases of appendicitis indicates immunological and non-immunological injury $[8,14,15]$. Type I hypersensitivity reaction causes degranulation of mast cells, release of mediators by mast cells might be another triggering factor for the sequence of events leading to appendicitis [12]. Correlation between mast cell density, neural ganglia hypertrophy and fibrosis in cases of chronic appendicitis as seen in the present study was in concordance with studies conducted by Nagaraj G et al [4], Kolur A et al [7], Sonti S et al [8], Sharma J et al [14], Kumaran C et al [15] and Naik R et al [16], mast cells have been implicated in the pathogenesis of fibrosis and neuronal hypertrophy in chronic appendicitis due to release of growth factors leading to fibroblastic and neuronal proliferation, this was in agreement with the findings in the other studies $[4,7,8,14,15,16]$. In the present study highest mean eosinophil count was seen in the mucosa of acute suppurative appendicitis and lowest eosinophil count was seen in the muscularis propria of chronic appendicitis. In acute suppurative appendicitis and acute appendicitis, mean eosinophil count was highest in mucosa followed by muscularis propria and then submucosa. In chronic appendicitis, mean eosinophil count was highest in mucosa followed by submucosa and then muscularis propria. Comparison of mean eosinophil count in different layers of appendix in various cases in the present study with study by Kolur A et al [7] is shown in Table 2 .

Kolur A et al [7] study showed highest mean eosinophil count in chronic appendicitis, followed by acute suppurative and then acute appendicitis and also the mucosa of chronic appendicitis showed highest count, muscularis propria of acute suppurative appendicitis showed lowest count. These findings were in contrary to the present study, where the highest mean eosinophil count was seen in the mucosa of acute suppurative appendicitis, lowest count was in the muscularis propria of chronic appendicitis. Aravindan KP [6] also observed that eosinophils were found in abundance in many cases of acute appendicitis involving all the layers of the appendix as seen in the present study. Aravindan KP [6] and Singh UR et al [5] found marked eosinophil infiltration in the muscular layer of acute appendicitis, where as in the present study it was seen in the mucosa of acute appendicitis.

Aravindan KP [6] suggested that infiltration of eosinophils was an early consequence of mediators released by mast cells in acute appendicitis. Eosinophils reach the site due to eosinophilic chemotactic factors present in the mast cells granules or due to histamine released by them. Similar postulation can be given in the present study. In the present study eosinophils were seen in all the appendicular lesions, their role in the pathogenesis of appendicitis can be postulated as Type I hypersensitivity reactions leading to recruitment of eosinophils and causing the degranulation of mast cells which discharge primary and secondary mediators of inflammation that play a role in the pathogenesis of appendicitis [7, 12].

However, no correlation was found between the mast cell and eosinophil count in appendix in the present study and also in the study by Kolur A et al [7], Singh UR et al [5].

\section{Conclusion}

Mast cells and eosinophils were seen in all the appendicular lesions in the present study. Hence, it was concluded that they have a role to play in the pathogenesis of appendicitis. It was postulated that appendicitis was due to allergic response. Type I hypersensitivity reactions leads to recruitment of eosinophils and discharge of primary and secondary mediators of inflammation by degranulation of mast cells. These were responsible for the pathogenesis of appendicitis. Mast cells have also been implicated in the pathogenesis of fibrosis and neuronal hypertrophy seen in chronic appendicitis due to release of growth factors leading to fibroblastic and neuronal proliferation.

\section{What the study adds to the existing knowledge?}

Many studies have been done on the significance of mast cells and eosinophils in appendicitis, this study also contributes to conclude that mast cells and eosinophils have a role to play in the pathogenesis of appendicitis. Presence of eosinophils contributes to the postulate that appendicitis was due to type I hypersensitive reaction and similarly presence of increased number of mast cells in chronic appendicitis supports that they have been implicated in causing neuronal hypertrophy and fibrosis.

\section{Author's contribution}

Dr. Priya: Study design, concept, statistical analysis. 
Dr. Sujata S. Giriyan: Data analysis, supervision of the study.

Findings: Nil; Conflict of Interest: None initiated Permission from IRB: Yes

\section{References}

1. Turner RJ. The Gastrointestinal Tract. In: Kumar V, Abbas KA, Aster CJ, editors. Robbins and Cotran Pathologic Basis of Disease. $9^{\text {th }}$ edition. New Delhi: Elsevier; 2015.

2. Shrestha R, Ranabhat SR, Tiwari M. Histopathologic analysis of appendectomy specimens. J Pathol Nepal. 2012; 2(3): 215-219. doi: https://doi.org/10.3126/jpn. v2i3. 6025

3. Liu CD, McFadden DW. Acute abdomen and appendix. Surgery: Sci Prin Pract. 1997;2:1246-61.

4. Nagaraj G, Das S, Venkatesha M, Lingiah HK. A comparative study of mast cells in appendix. Int J Med Sci Pub Health. 2015;4(11):1611-1615. doi: 10.5455/ ijmsph.2015.02032015330.

5. Singh UR, Malhotra A, Bhatia A. Eosinophils, mast cells, nerves and ganglion cells in appendicitis. Indian J Surg. 2008;70(5):231-234. doi: 10.1007/s12262-0080066-0. Epub 2008 Nov 26.

6. Aravindan KP. Eosinophils in acute appendicitis: possible significance. Indian J Pathol Microbiol. 1997; 40(4):491-498.

7. Kolur A, Patil AM, Agarwal V, Yendigiri S, Sajjanar BB. The Significance of mast cells and eosinophils counts in surgically resected appendix. J Interdisciplin Histopathol. 2014;2(3):150-153.

\section{Original Research Article}

8. Sonti S. A study on the mast cells in appendix. J Clin Diagn Res. 2012;6(7):1276-1279.

9. Kothadia JP, Katz S, Ginzburg L. Chronic appendicitis: uncommon cause of chronic abdominal pain. Therapeut Advan Gastroenterol. 2015; 8 (3): $160-162$

10. Leardi S, Delmonaco S, Minerva Chir, Ventura T, Chiominto A, De Rubeis G. Recurrent abdominal pain and chronic appendicitis. Minerva Chir. 2000;55(1-2): 39-44.

11. Bhramaramba K, Srujana S, Ramadevi P, Kumar OS. Role of mast cells and neuronal hypertrophy in acute appendicitis. Int Arch Integ Med. 2016;3(11): 94102.

12. Mysorekar VV, Chanda S, Dandeka CP. Mast cells in surgically resected appendices. Indian $\mathrm{J}$ Pathol Microbiol. 2006;49(2):229-233.

13. Verma A, Shinde RM, Ghatge RM, Gupta S, Inamdar AA, Sujata N. A study of mast cells in surgically resected appendix. Int J Adv Res. 2016; 4 (11): 1547-1553. doi: $10.21474 /$ IJAR01/2245.

14. Sharma J, Chaudhary N, Bhargava S, Agrawal I. Role of Mast Cells in Appendicitis. Int J Health Sci Res. May 2017;7(5):37-41.

15. Kumaran C, Divya Lakshmi L. Mast cell in appendicitis: A study. J Evidence Med Healthcare. 2015; 2(34):5165- 5170. doi: 10.18410/jebmh/2015/719

16. Naik R, Gowda RJ, Pai MR. Mast cell count in surgically resected appendices. J Indian Med Assoc. 1997;95(11):571-572.

\section{How to cite this article?}

Priya, Giriyan S.S.Study of mast cell and eosinophil count in surgically resected appendix.Trop J Path Micro 2019;5(9):728-734.doi:10.17511/jopm.2019.i09.18. 